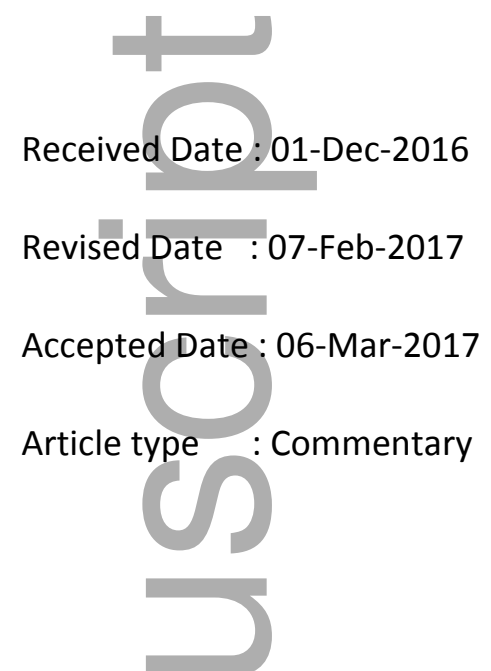

Title: Diabetic Medicine

Created by: Maria Davie

Email proofs to: sis11@le.ac.uk

Article no.: DME-2016-00884

Article type: Commentary

Figures:1; Tables:0; Equations:0; References: 17

Short title/Authors running head: Commentary $\bullet$ S. Seidu et al.

\title{
Commentary
}

\section{Integrated primary care: is this the solution to the diabetes epidemic?}

S. Seidu ${ }^{1,2}$, M. J. Davies ${ }^{1,2}$, A. Farooqi ${ }^{3}$ and K. Khunti ${ }^{1,2}$

${ }^{1}$ Leicester Diabetes Centre, Leicester General Hospital, ${ }^{2}$ Diabetes Research Centre, University of Leicester and ${ }^{3}$ Leicester City Clinical Commissioning Group, Leicester, UK

Accepted

This is the author manuscript accepted for publication and has undergone full peer review but has not been through the copyediting, typesetting, pagination and proofreading process, which may lead to differences between this version and the Version of Record. Please cite this article as doi: 10.1111/dme.13348

This article is protected by copyright. All rights reserved 
Correspondence to: Samuel Seidu. E-mail: sis11@le.ac.uk

The prevalence of Type 2 diabetes mellitus is rising exponentially across the globe [1], mainly as a result of changes in lifestyle [2]. Other factors accounting for this rise include proactive screening, people with diabetes living longer and an ageing general population [3]. With the increasing age comes an increase in the prevalence of chronic diseases and multimorbidity [4]. People with diabetes not only develop complications directly related to the condition, but also often have multimorbidities in addition to their diabetes [4]. Despite the challenges the rising prevalence presents, there have been some improvements in mortality rates [5], partly as a result of the increased use of statins, antihypertensive therapies and an increase in smoking cessation rates [6].

Current strategies for managing diabetes focus on encouraging clinicians and people with diabetes to adopt evidence-based, often single-strategy, interventions; however, far more complex strategies are often needed. For these complex and multiple interventions to be effective, various diabetes care models have been proposed, and include multidisciplinary teams and multifaceted interventions [7] to deal with the complexity of demand created by diabetes and its comorbid conditions. The chronic care model, an example of such an integrated model of care, focuses on effective integration of care around the individual patient [8]. This integration of care normally comprises specialists, sometimes working in community diabetes clinics, with the support of generalists with special interest in diabetes, specialist nurses, dieticians and podiatrists. Yet a recent cluster randomized controlled trial examining the impact of integrated diabetes clinics highlighted the fact that these have little effect on intermediate outcomes but are associated with higher costs to the health services [9]. There is therefore an urgent need for healthcare providers and policy-makers to generate evidence on high-quality cost-effective alternatives that can achieve better patient outcomes, while maintaining continuity. In many developed countries, primary care physicians, family physicians or generalist clinicians maintain a registered patient list and have a continuous knowledge and relationship with the individuals with diabetes. As a result of the knowledge of the bio-psychosocial histories of people living with diabetes, the generalist is suitably equipped to exercise professional judgment in their management of the people with diabetes and other multimorbid conditions beyond the guidelines. They bring their own personal knowledge of the patient to the decision-making process, integrating this with research evidence to make informed judgments. As well as these advantages, patients may also benefit by having their care provided close to their home. Healthcare systems as a whole could potentially therefore benefit because primary care-based care is likely to be more costeffective [10]. Emergency admissions resulting from diabetes or its complications are an unexpected health event and it is this complex group that should ideally be managed in 
specialist units. Of all the people with diabetes admitted in 2015 in England and Wales, only 9\% were admitted specifically because of their diabetes condition [11]. Thus, more specialist care is neither a good solution nor an alternative for the inadequate management of the vast majority of people with diabetes.

Good quality service evaluations are lacking, but emerging data on structured diabetes service redesign, involving enhanced diabetes-skilled primary care physicians, nurses and healthcare assistants in the primary care settings have shown these models to be at least as effective in reducing hospitalizations, outpatient attendance or admissions for diabetes-related complications compared with an integrated specialist-community care core diabetes service [12]. In this evaluation the primary care enhancement initially consisted of upskilling the generalist in the up-to-date management of diabetes. The key to the success of these models includes primary care physicians with an interest in diabetes undertaking enhanced skills training. A practice nurse with similar or equivalent diabetes qualifications supporting the primary care physician is also important. The model of care needs to focus on care planning for people with diabetes who have multi-morbidities, those who are housebound and those with poor glycaemic control. The teams need to meet up regularly with specialist support to discuss complex diabetes cases selected from their practices. Self-management support through facilitating skills-based learning and patient empowerment is also encouraged. Regular audits of outpatient attendances and hospital admissions also need to be discussed and fed back to practices, with people with stable glycaemic control discharged back to primary care. All clinicians need to be guided by evidence-based clinical care pathways for various aspects of diabetes care. A schematic representation of the aforementioned model of care is given in Fig. 1, and illustrates some of the interventions used in the enhanced practices. While we accept that inadequate primary care is seldom the only reason for inadequate diabetes management, we believe that this enhanced primary care model could potentially provide longer-lasting benefits because continuity of care for the patient can be guaranteed closer to their home. In the Netherlands, where $\sim 90 \%$ of people with Type 2 diabetes are treated in primary care, good cardio-metabolic control is achieved sometimes with less frequent visits to the primary care physician. This results in considerable cost savings $[13,14]$.

The challenge of this primary care-centred model of diabetes care is its sustainability. Even in advanced economies, recruitment and retention of primary care teams can be a challenge, mainly because of a combination of increasing workload and poor resource allocation. In the UK for example, the average consultation rate per year per general practitioner increased from 3.9 in 1995 to 6.2 in 2014 [15], with most general practitioners now seeing, on average, 18 patients in a 4-hour session [16]; however, the small rise in general practice registrar 
recruitment from 2006 to date has been dwarfed by the exponential rise in hospital specialist registrars [14].

In the USA, as a result of the significant primary care physician shortage, internal medicine residency programmes are a major source of generalist physicians [17]. In 2010, over onethird of practising primary care physicians were general internists [17]. The emphasis of our medical educational systems on disease- or organ-based specialization rather than wholeperson medicine is a major contributory factor to the disproportionate workload arrangement, which could in turn compromise the success of any primary care-centred diabetes care model. Strengthening primary care teams could be part of the solution to the huge burden of diabetes care facing healthcare systems globally.

\section{References}

1. Whiting DR, Guariguata L, Weil C, Shaw J. IDF diabetes atlas: Global estimates of the prevalence of diabetes for 2011 and 2030. Diabetes Res Clin Pract 2011; 94: 311-321.

2. Tuomilehto J, Wolf E. Primary prevention of diabetes mellitus. Diabetes Care 1987; 10: $238-248$.

3. Hu FB. Globalization of diabetes: The role of diet, lifestyle, and genes. Diabetes Care 2011;34:1249-1257.

4. Barnett K, Mercer SW, Norbury M, Watt G, Wyke S, Guthrie B. Epidemiology of multimorbidity and implications for health care, research, and medical education: A crosssectional study. Lancet 2012; 380: 37-43.

5. Lipscombe LL, Hux JE. Trends in diabetes prevalence, incidence, and mortality in ontario, canada 1995-2005: A population-based study. Lancet 2007; 369: 750-756.

6. Mendis S, Puska P, Norrving B. Global atlas on cardiovascular disease prevention and control. World Health Organization; 2011.

7. Seidu S, Walker N, Bodicoat D, Davies M, Khunti K. A systematic review of interventions targeting primary care or community based professionals on cardio-metabolic risk factor control in people with diabetes. Diabetes Res Clin Pract 2016;113:1-13. 
8. Bodenheimer T, Wagner EH, Grumbach K. Improving primary care for patients with chronic illness: The chronic care model, part 2. JAMA 2002;288:1909-1914.

9. Wilson A, O'Hare JP, Hardy, Raymond N, Szczepura A, Crossman R et al. Evaluation of the clinical and cost effectiveness of intermediate care clinics for diabetes (ICCD): A multicentre cluster randomised controlled trial. PLoS One 2014; 9(4):e93964.

10. Huang ES, Zhang Q, Brown SE, Drum ML, Meltzer DO, Chin MH. The Cost-Effectiveness of improving diabetes care in US federally qualified community health centers. Health Serv Res 2007; 42: 2174-2193.

11. Diabetes U. Diabetes in the UK 2011-12 key statistics on diabetes. Available at: http://www.diabetes.org.uk/Professionals/Publications-reports-andresources/Reportsstatistics-and-case-studies/Reports/Diabetes-in-the-UK-2011/. Last accessed 28 September 2012.

12. Seidu S, Bodicoat D, Davies M, Daly H, Stribling B, Farooqi A et al. Evaluating the impact of an enhanced primary care diabetes service on diabetes outcomes: A before-after study. Primary Care Diabetes 2016; doi: 10.1016/j.pcd.2016.09.005. [Epub ahead of print].

13. Boels AM, Hart HE, Rutten GE, Vos RC. Personalised treatment targets in type 2 diabetes patients: The dutch approach. Primary Care Diabetes 2017; 11: 71-77.

14. Wermeling P, Gorter K, Stellato R, De Wit G, Beulens J, Rutten G. Effectiveness and cost-effectiveness of 3 - monthly versus 6 - monthly monitoring of well- contr olled type 2 diabetes patients: A pragmatic randomised controlled patient-preference equivalence trial in primary care (EFFIMODI study). Diabetes Obes Metab 2014;16:841-849.

15. General practice trends in the UK to 2014. Available at: http://content.digital.nhs.uk/media/18173/General-Practice-Trends-in-the-UK-to2014/pdf/gen-prac-trends-2014.pdf. Updated 2015.

16. A day in the life of a GP. Available at: https://www.kingsfund.org.uk/publications/articles/gp-day-in-the-life. Updated 2016.

17. Petterson SM, Liaw WR, Phillips RL,Jr, Rabin DL, Meyers DS, Bazemore AW. Projecting US primary care physician workforce needs: 2010-2025. Ann Fam Med 2012;10:503-509. 
FIGURE 1 New enhanced model of care. GLP-1 Rx, glucagon-like peptide-1 treatment; QOF, Quality and Outcomes Framework.

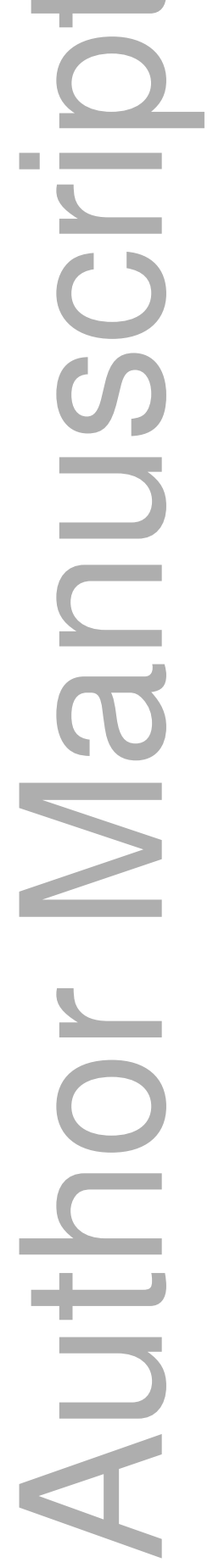




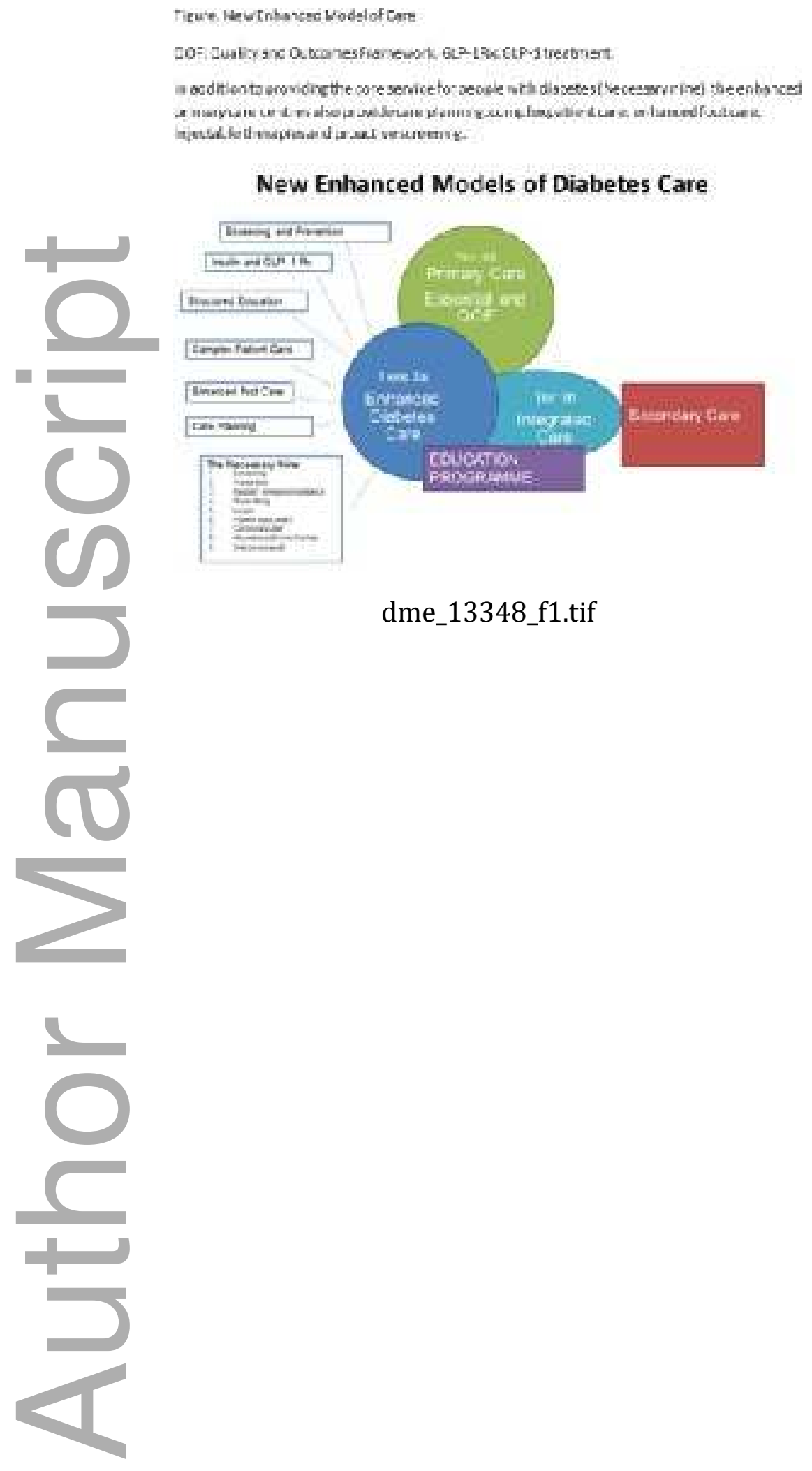

This article is protected by copyright. All rights reserved 


\section{University Library}

\section{- M M N E R VA A gateway to Melbourne's research publications}

Minerva Access is the Institutional Repository of The University of Melbourne

Author/s:

Seidu, S;Davies, MJ;Farooqi, A;Khunti, K

Title:

Integrated primary care: is this the solution to the diabetes epidemic?

Date:

2017-06

Citation:

Seidu, S., Davies, M. J., Faroogi, A. \& Khunti, K. (2017). Integrated primary care: is this the solution to the diabetes epidemic?. Diabet Med, 34 (6), pp.748-750. https://doi.org/10.1111/ dme.13348.

Persistent Link:

http://hdl.handle.net/11343/292899 